\title{
The Place of Eucalyptus Within the Vegetation of Mesaoria Plain (Cyprus) and the Views of Vegetation Geography Lecturers
}

\author{
Serkan IIlseven ${ }^{1}$, Mert Baştaş ${ }^{2 *}$ \\ ${ }^{1}$ Near East University, Department of Environmental Education \& Management, CYPRUS \\ ${ }^{2}$ Near East University, Near East Institute, CYPRUS
}

Received 2 December 2017 - Revised 22 March 2018 - Accepted 4 May 2018

\begin{abstract}
A wide range of botanists, ecologists, foresters and geographers see eucalyptuses as a potential danger for the environment, which can be considered as an asset instead. This study includes the views that eucalyptus trees do not change the ecological environment, neither can have a major influence on it, unless the natural vegetation of an area is vastly removed and eucalyptus trees are planted in their place. In Cyprus, this is not the case, Eucalyptuses were planted individually or in small groves only in the extremely dry Mesaoria Region extending from Güzelyurt (Morpho) Bay to Mağusa (Famagusta) Bay. On the other hand, planting eucalyptus trees in the chalky and clay hills of the Mesaoria, on the dry rendzina in the Pahna formations and in the vast Flysch Series which are in contact with the southern hillsides of the Kyrenia Mountains, is indispensible for ecological support. The most important factor in the success of eucalyptus planting in Mesaoria is the extremely dry climate of the region. In this study, discussion is carried out among the the views of vegetation geography lecturers and observations around the eucalyptuses of island.
\end{abstract}

Keywords: eucalyptus, Mesaoria, Cyprus, vegetation, ecology

\section{INTRODUCTION}

The eucalyptus first came to Cyprus through the French arborist P.G. Madon. Madon, who was then sent to Cyprus in 1876 by the ottoman administration in order to prepare a report concerning the existing forests, published his first report Replanting of island of the Cyprus in 1880 and his second report The preservation of the forests of the island of Cyprus in 1881 (Y1kıc1, 2015). Both reports of Madon as well as the publication of S. Baker called Cyprus as I saw it indicated that in addition to the Mesaoria, the Kyrenia Mountains was also bare in Cyprus. During that period, the administration in Cyprus was taken over by the British after the Ottomans and through the utilization of political vacuum; the public were cut down the trees with an approach that would be even called a massacre. At the last quarter of $19^{\text {th }}$ century, there had been almost no tree on the Kyrenia Mountains.

In Algeria, where the French arborist Madon lived for a period, the eucalyptus trees were widely used for the improvement of health conditions during the fight against malaria. Following the eucalyptus planting performed in more than thirty areas in Algeria with poor health conditions, the mortality rate from malaria dropped to first 33 in thousand by 1872 and 26 in thousand by 1876 while this figure was 46.3 in thousand between 1853-1856 (Y1k1c1,2015). With the motivation from these outcomes, Medon prepared his report following his studies in Cyprus. He indicated in his report that the species like Eucalyptus resinifera, Eucalyptus tereticornis, Eucalyptus resdonii, Eucalyptus maculata, Eucalyptus pendulosa, Eucalyptus sideroxylon, Eucalyptus viminalis, Eucalyptus botroyides, Eucalyptus colossa, Eucalyptus occidentalis, Eucalyptus robusta, Eucalyptus persicifolia were particularly suitable to use in the marsh areas of Cyprus. Therefore, the eucalyptus saplings were grown in the nurseries located in Nicosia and Larnaca and then used especially during the plantings in Nicosia, Famagusta and Larnaca.

Eucalyptuses have a vital role in pollen production. The number of flowering plants on the Mesaoria plain is very few. Since only some of the eucalyptus species flower during this long and dry period, the eucalyptus groves created in Mesaoria would significantly contribute to the beekeeping sector. E. Torquata that mainly flowers in

(C) 2018 by the authors; licensee Modestum Ltd., UK. This article is an open access article distributed under the terms and conditions of the Creative Commons Attribution License (http://creativecommons.org/licenses/by/4.0/).

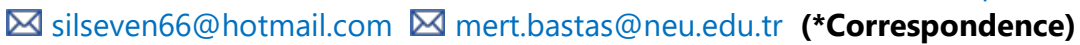




\section{Contribution of this paper to the literature}

- Eucalyptus trees are suitable on the $5 \%$ of irrigable agriculture lands, as they do not bear any negative impact.

- $\quad$ Although it is argued that the eucalyptus tree empties the underground aquifers with its deep root systems, the results of the study and observations shows that eucalyptus species in Cyprus has no more than 4 meter-deep roots.

- Despite the structured interview results derived from Vegetation Lecturers support the idea that Eucalyptuses harm the mesaoria plain water and moist structure of the soil, the observations of the study and the figures proves the opposite that the mesaoria plain benefits from the eucalyptuses.

March-April, E. camaldulensis, E. gomphocephala as well as E.woodwardii flowering at the end of summer particularly October-November-December are the only feeding area for honey bees. According to our studies, the other species that may be important for the bee keeping are the eucalyptus species that flower at different periods of summer as E. melliodora, E. poroza, E. leucoxylon, E. Poroza, E.odorata, E. sideroxylon. Through the creation of eucalyptus groves with the abovementioned species in the Mesaoria plain, which has a sparse vegetation, the bee keepers would be able to continue their practices on the wide fields of Mesaoria Plain as they were changing the places of bees.

The eucalyptuses have resistance to fire. Unlike the coniferous trees, the majority of eucalyptus species are not affected by fire and they may come into leaf just after fires (Ayata,2008). Eucalyptus species possess a range of adaptive traits which provide a high resilience to the effects of fire; these may include large numbers of aerial perennating buds, a specialized subterranean regeneration organ (lignotuber), protective bark, and woody, fireresistant seed (Wellington \& Noble, 1985). Hence, among all the calabrian pines and cypress trees, tens of eucalyptus trees were come into leaf after the fire on Kyrenia Mountains in 1995. Therefore, it is important to increase the utilization rate of eucalyptuses in the places with high risk of fire and areas close to the picnic sites.

Within the framework of United Nations Environment Programme and various development programmes, the hybrid planting systems used for reforestation in many countries are promoted and the eucalyptus trees are used accordingly. However, recently some groups started to claim that it is not possible to grow anything under the eucalyptus trees and such claim was spread as a wrong opinion. Whereas the petal structure of eucalyptuses is nonrigid that allows the sunrays to pass through. Considering other tree species that form a forest or grove in Cyprus, the eucalyptus trees allow the growth of other tree or shrub more. The eucalyptus trees are the most vital accommodation point for the little birds, woodpigeon (Fassa) and raptors living in the Mesaoria Plain other than a couple of trees. According to our studies, almost all of the bushes and other tree species growing under the eucalyptuses were able to be still in place through the seeds of fruits eaten by these birds. Consequently; the natural existence of plants like the lycium (Lycium schweinfurthii, Lycium ferocissimum), Gonnara=wild lotus (Zyzyphus lotus), Buckthorn (Rhamnus alaternus, Rhamnus oleoides), hawthorn (Crataegus azarolus), fig (Ficus carica), wild olive (Olea oleaster), almond (Prunus dulcis) in the Mesaoria is related with the birds that use the eucalyptus trees for accommodation. Birds can be useful indicators for biodiversity as a whole, and the depopulated and depauperate avian community within the eucalyptus plantations will likely lead to reduced provision of many ecosystem services in this region if the spatial extent of plantations continues to expand. (Phifer, et.al, 2017)

Eucalyptus trees (Eucalyptus camaldulensis Dehnh.) can occasionally be seen in valleys at the centre of the island. (Illseven, 2017). This study aims to identify the place of eucalyptus groves within the Masaoria (İçova) Plain between the Morphou Bay and the Famagusta Bay under the vegetation of Cyprus. This study also aims to assess the effects of eucalyptus grove on the flora and fauna of Mesaoria, and the floristic features of eucalyptus and their suitability and effects of the related features from the Cyprus perspective. Together with the observations on the field face to face interviews are carried out to determine the views of the Vegetation Geography Lecturers.

\section{METHOD}

The Mesaoria Plain (İçova) was selected as the study zone, which has the surface area of 25-30 km width and 90-95 km length between the Kyrenia Mountains and Trodoos Mountains from Lefke on the west and Famagusta Bay in the east (Illseven, Hidırer, Tümer 2016). The material of our study is particularly the eucalyptus planted during the British colonial period. Since there is not any previous (directly related) research, article and thesis regarding the areas that the eucalyptus planted, the field studies constituted the basis of our study. During the study period, the eucalyptus groves and the eucalyptus valleys in Mesaoria were visited at different times and the aim of such field visits were to determine the interaction of the eucalyptus with the local vegetation and their impact on the wild life. The eucalyptus leaf and seeds collected from the related areas were classified in accordance with the Alevkayası and the Near East University Herbarium collections and with the wide experiences of Zorlu Yikıc1. While the plant samples were collected from the field, the plants growing at the bottom of eucalyptus trees were 
also identified and then found as fully compatible with the eucalyptus. The forestry maps with 1/15000 scale from the Forestry Departments of Cyprus were used.

Fifteen vegetation lecturer from different four universities of Cyprus have given their views on the eucalyptuses place in the Mesaoria.

\section{RESULTS}

Table 1. Views of Vegetation Lecturers of Eucalyptus

\begin{tabular}{lccc}
\hline & Yes & No & No idea \\
\hline Eucalyptuses harm the mesaiora plain water and moist structure of the soil & $100 \%$ & 0 & 0 \\
\hline Changes the Ecology & $76 \%$ & $12 \%$ & $12 \%$ \\
\hline Flora under the forest is changed by the Eucalyptuses & $62 \%$ & $25 \%$ & $13 \%$ \\
\hline Decrease the Bird Population & $62 \%$ & $13 \%$ & $25 \%$ \\
\hline Make the reptiles run away & $50 \%$ & $50 \%$ & 0 \\
\hline
\end{tabular}

After structured interviews Vegetation Lecturers support the idea that Eucalyptuses harm the mesaiora plain water and moist structure of the soil. Participants with \%62 percent believe that the forest flora is badly affected because of the leaves of eucalyptus and bird population is harmed with a similar percentage. Fifty percent of the lecturers replied that reptiles are running aways from the branches of the eucalyptus.

\section{Place of Eucalyptuses within the Ecology of Cyprus and Observations}

There are 62 types of eucalyptus species identified in Cyprus, which 47 of such are classified, 15 non-classified or hybrid $\left(\mathrm{Y}_{1} \mathrm{k}_{1 \mathrm{c}}, 2015\right)$. Out of more than 800 eucalyptus species, around 60 species were planted in the conditions of our country; when other species that are resistant to the salinity and drought are considered, there is a need to have more detailed origin trials, seed trials and researches on the production of superior genotypes through vegetative and plant tissue methods.

In Cyprus, the depth of aquifer in Gemikonağ is 40-50 meter, 80-100 in Yeşilyurt, 100-145 meter in Morphou. Even the absolute root depth of Eucalyptus camaldulensis with the deepest root systems among the eucalyptus species in Cyprus has no more than 6 meter-deep roots. While such depth may slightly vary depending on the geological structure and type of soil, our researches indicated that the average root depth of eucalyptuses is $4 \mathrm{~m}$. The eucalyptus utilizes water through its hairy roots on the surface or just below the surface. In other words, the eucalyptus trees do not extract water from the deep aquifers contrary to the common belief. (See Figure $\mathbf{1}$ and Figure 2) They grow well where the ground water is high. Thus, they showed good growth at the intersection of Kanlıdere, Jinnar Stream, Asi Stream and streams from Flysch through benefitting from the ground water.

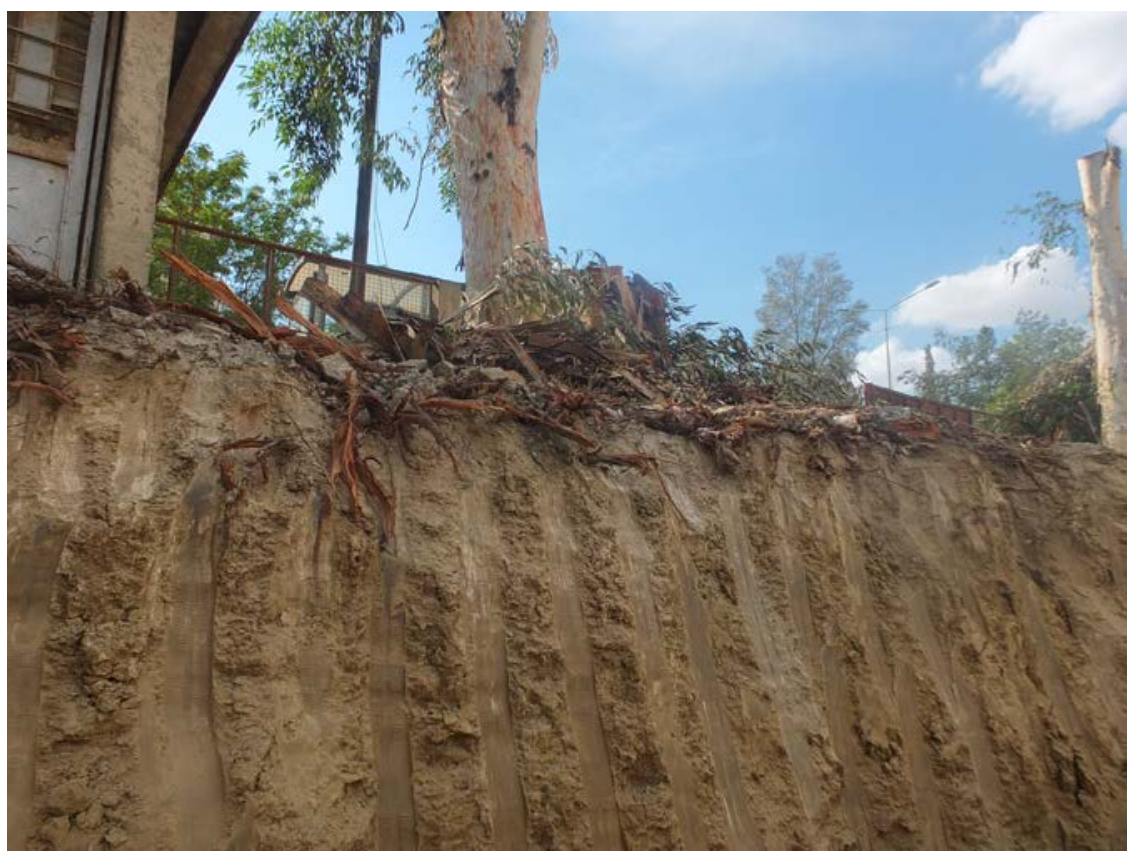

Figure 1. An Eucalyptus tree in Nicosia without having deep roots 


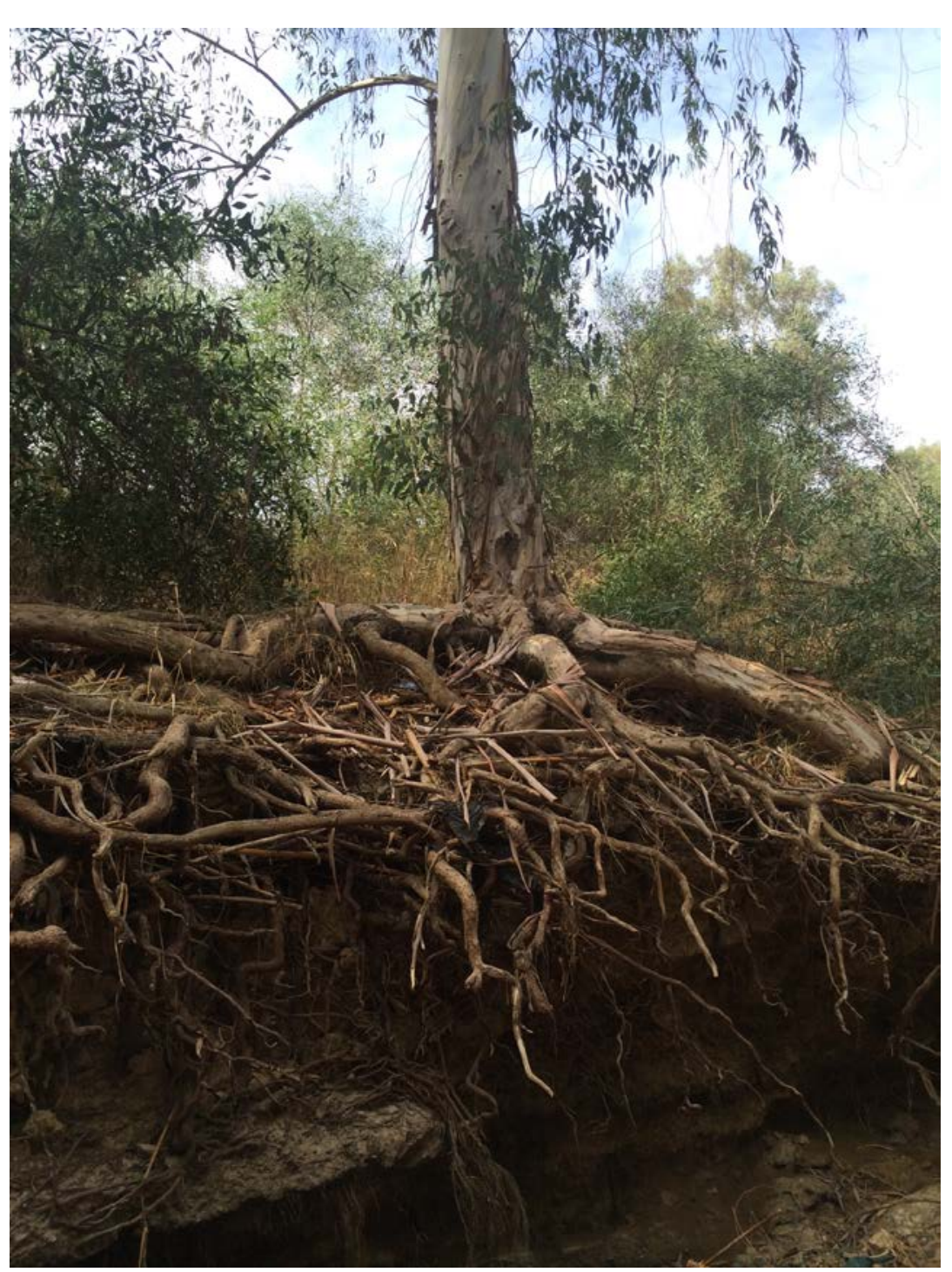

Figure 2. Eucalyptus having hairy roots in Famagusta Province

The eucalyptus utilizes water through its hairy roots on the surface or just below the surface. In other words, the eucalyptus trees do not extract water from the deep aquifers contrary to the common belief.

Değirmenlik Forests located between Haspolat - Güngör is one of the areas with major eucalyptus plantation. These meters-deep flysch fields do not have any ground water or aquifer. The sole water resource for the eucalyptus trees in this region is the low level of rainfall. Even in 2008 when the rainfall was at the minimum level, Eucalyptus occidentalis, Eucalyptus brockwayii and Eucalyptus torquata were not affected from such condition and maintained in the area and even continued sorting; the trials of Calabrian pine (Pinus brutia), Aleppo Pine (Pinus halepinsus) and Cypress trees (Cupressus sempervirens) showed desiccation up to 25\% in the Mesaoria Plain (Illseven,2004). Even this single example explicitly shows that the eucalyptuses in Mesaoria use water effectively and grow taller more compared with other species. This is to say; the claims that the eucalyptus trees push the hydrological cycle back are unjustifiable. On the contrary, they use the same amount of water as the other species and store more carbon (Y1k1c1, 2015).

Up to now, the rate of eucalyptus trees used by the Turkish Cypriot Department of Forestry in the afforestation is not more than $2 \%$. Almost all of them were planted on the Yazılitepe formation, Flysch series, marly cliffs and chalky hills, which are dry and arid lands as it is not possible to grow any other species.

The Mesaoria Plain, which is suitable for the growth of eucalyptus are continuously planted for the barley farming. Since the upper part of soil that has a depth of $20-25 \mathrm{~cm}$ is planted without fallowing, the soils are exhausted and weakened from their mineral content. However, the deeper parts of soil have not been used and are 
rich in organic matter. When the fields in Mesaoria will become irrigable agricultural lands with the water pipe line project from turkey, then at least a part of the lands may be allocated for the eucalyptus trees.

The criticism that the underbrush vegetation has difficulties to grow in the eucalyptus groves is based on the lack of natural vegetation on such areas. Thus, Lycium schweinfurthii as a natural shrub from the Akama peninsula, Paphos, Nicosia, Larnaca and Famagusta and Lycium ferocissimum, an exotic species grow on lower areas under the eucalyptus trees. The eucalyptuses are precursor trees for such species and Lyciums following the eucalyptuses continue their growth. According to our studies, the Lycium bushes were found under the eucalyptus trees in the Akdeniz village on the west to the east of Mesaoria and even Karpaz Peninsula, Kavallis Forest in Yeşilköy. In addition to the poterium spinosum (Sarcopoterium sipinosum) as one of the garrigue vegetation components on the Flysh lands, buckthorn (Rhamnus alaternus), asparagus (Asparagus stipularis) and immortelle (Noaea mucronata), Eucalyptus occidentalis from West Australia as one of the shorter eucalyptus species may show natural vegetation under Eucalyptus astringens, Eucalyptus brockwayii and Eucalyptus sargenti. Even the calabrian tree can grow under the eucalyptus trees in the Değirmenlik Forest where there is no water and intensive vaporisation in summers. Young olive saplings have grown in the eucalyptus grove between the hybrid of calabrian tree (Pinus brutia) and Aleppo pine (Pinus halepinsis) in the north of Ercan Airport. These olive saplings were carried to the are with the woodpigeon and pigeons. The seeds brought by the birds were able to germinate since the spring flowing within the grove keeps the land humid during the rainfall season. Another great examples are chaste tree (Vitex agnuscastus) and terebinth (Pistacia terebinthus) growing under the eucalyptus trees along the Yedidalga Stream. Due to the luminous structure of eucalyptus trees, the related bushes had the chance to grow on the ground.

The use of eucalyptus in Mesaoria is an ecological obligation. Due to the climate structure as well as the geological and hydrological structure, there is no possibility to grow any other tree species. The trees that can grow on the chalky and clayish hills, dry rendzina caused by the Pahna formation and wide flysch series are Cyprus acacia, iron tree and eucalyptus species. No other forest species can grow in the Mesaoria $\left(Y_{1} k_{1} 11_{1}, 2015\right)$. The surface flow under the eucalyptus trees as individual tress or small groves planted in the past in Cyprus is slightly less than the other regions. Therefore, the eucalyptus plantations must be ensured in the steep and strong sloping dry lands in Mesaoria for the prevention of erosion.

\section{DISCUSSION}

The annual average rainfall in Mesaoria is below $340 \mathrm{~mm}$. The areas that get the least rainfall in Cyprus are the Morphou Plain (286 mm), which is the western extension of this plain, and Dörtyol that located in the middle (278 $\mathrm{mm}$ ) (İlseven, Hidırer,Tümer 2014). Under such climatic conditions, the origin of species that might grow in the Mesaoria other than the savannah plants is Australia. Other than the eucalyptus trees (Eucalyptus Ssp.) in Mesaoria that were brought from Australia during the British administration and showed great development, the trees found in Mesaoria are Ironwood tree (Casuarina equisetifolia), Cyprus mimosa (Acacia cyanophylla) and Parkinsonia (Parkinsonia aculeata) (İlseven,2016).

The main reason of the successful eucalyptus planting in Mesaoria is the significantly arid climate that prevents the invasion of shrubs. This situation varies in the Kyrenia Mountains and Trodoos Mountains. The eucalyptus trees cannot resist the competition of shrubs in the areas close to the mountains in the North and South. Due to their luminous shadows, the shrubs invade the eucalyptuses when there is a slight part way through the planting in the forest zone or surrounding. In almost each spacing, the eucalyptus trees have local undergrowth bushes.

The eucalyptuses that should be considered as a great asset in terms of ecology are regarded as a potential threat for environment by many botanic, ecology, forestry and geography experts both in Cyprus and Turkey. The experts argued in their publications that the eucalyptus tree empties the underground aquifers with the deep root systems, contaminates the soil by excreting toxins, drains all the plant nutrients in the soil, cannot prevent the soil from erosion since it cannot prevent the surface flow, casts the wild animals away and have no value as animal feed and green fertilizer (Görcelioğlu1988; Amazonas et.al, 2017). However, in the results of our study and observations, even the absolute root depth of Eucalyptus camaldulensis with the deepest root systems among the eucalyptus species in Cyprus has no more than 4 meter-deep roots (Y1kic1, 2015). 


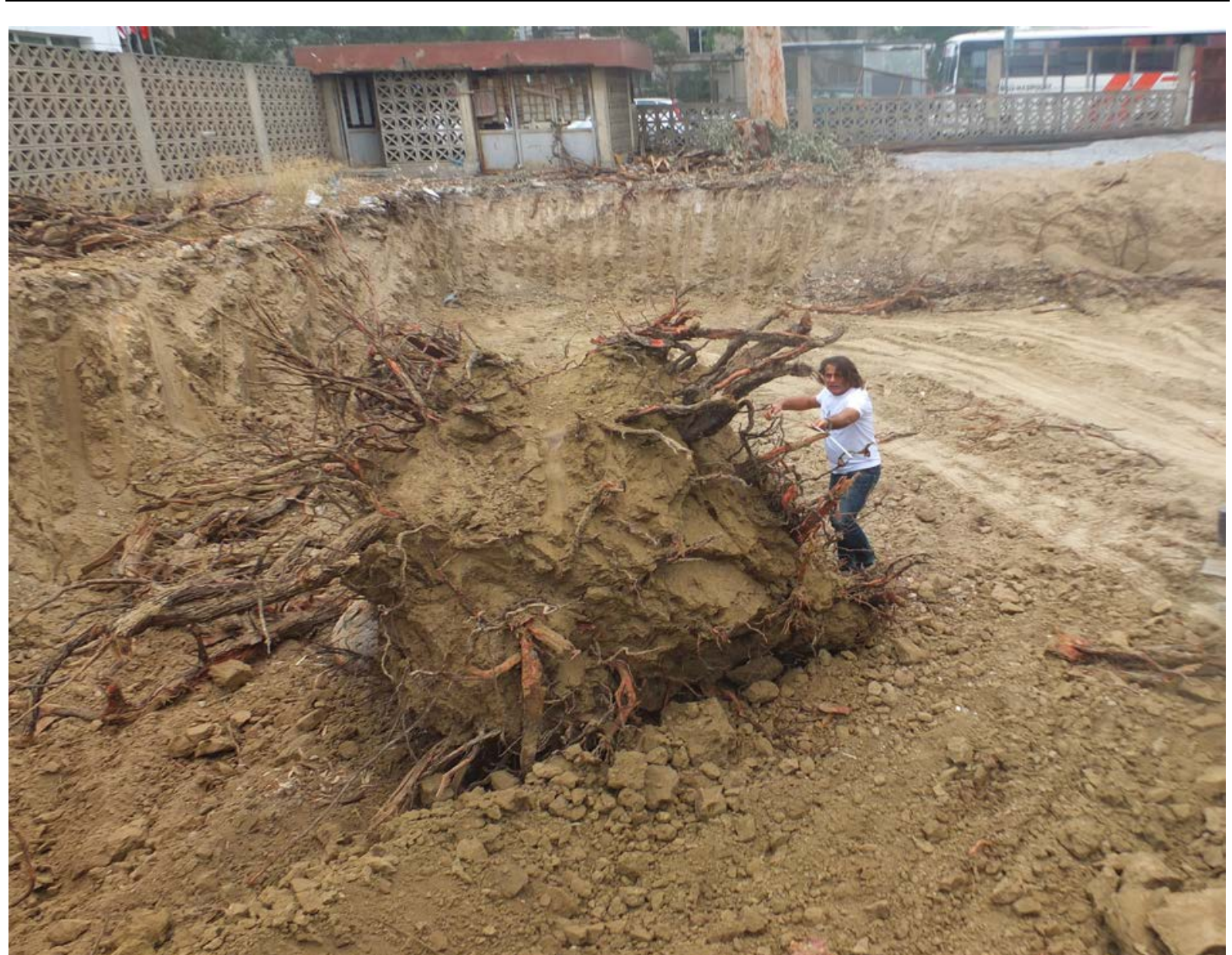

Figure 3. While such depth may slightly vary depending on the geological structure and type of soil, our researches indicated that the average root depth of eucalyptuses is $4 \mathrm{~m}$.

As it can be seen in Figure 2, the eucalyptus utilizes water through its hairy roots on the surface or just below the surface. This is paralel with the studies of Ashton (1975). He finds out that in swamps, vertical roots are short and trees are very unstable.

During XVII. And XIX. centuries, eucalyptus trees were used to dry the swamps, which were the source of malaria in Cyprus, Italy, Algeria, Turkey, Israel and Uganda. Therefore, due to such features, the eucalyptus trees are mainly used to control the ground water level in the wide lands where the salinity levels of soil is high due to the high groundwater level (Görcelioğlu, 1988; De Toledo, Souza, Bertolli, S. C.,2015).

The impact of eucalyptuses on the humidity level of soil is explicit after the age of 5 . Throughout the year, the groundwater deficit at the eucalyptus groves is the same with the natural forests. The main reason why eucalyptus trees are one of the exotic species preferred in an extremely dry plain like Mesaoria plain in Cyprus is its strong adaptation features. The majority of eucalyptus species developed the control mechanism that they have developed to overcome the annual dry period during the Australian rain season in Cyprus too and controlled the transpiration.

There is no difference between the impact of eucalyptus plantations on the climate and vegetation comprised of other trees or shrubs that can grow in the same ecological conditions on the climate. The eucalyptus underbrush formations can easily access to heat and rain when compared with other evergreen plants. Due to its rare branches and diathermic leaf structure, the rain and heat can easily reach to the shrub flora. Just like other vegetation formations, the eucalyptuses transform the fog to rainfall and create a positive impact on the climate. The interception loss of the eucalyptus trees are generally between $11 \%$ and $20 \%$, which is less than pine species but more that shrub vegetation (Y1k1c1, 2015).

The eucalyptus trees may change the ecology in a country or have a major impact on the ecology only if the eucalyptus trees are planted in wide areas instead of the natural vegetation, which is not applicable for Cyprus. Eucalyptuses were only planted individually or in small groves in the extremely dry Mesaoria Region extending from Morphou Bay to Famagusta Bay. The climate condition in such a wide area is not suitable to have other shrub or undergrowth naturally other than the shrubs of Prosopis farcta and Zizphus lotus. 


\section{CONCLUSION}

Eucalyptus trees cannot change the ecology, neither can have a major influence on it, unless the natural vegetation of an area is vastly removed and eucalyptus trees are planted in their place. In Cyprus, this is not the case. Eucalyptuses were planted individually or in small groves only in the extremely dry Mesaoria Region extending from Güzelyurt (Morpho) Bay to Mağusa (Famagusta) Bay. In majority of this vast land, the climate conditions are not suitable to naturally grow bushes or shrubs other than Prosopis farcta and Zizphus zizyphus.

Although the structured interview results derived from Vegetation Lecturers support the idea that Eucalyptuses harm the mesaoria plain water and moist structure of the soil, the observations of the study and the figures proves the opposite that the mesaoria plain benefits from the eucalyptuses.

In accordance with the drought conditions, the species from inland and abroad are required that grow fast for the reservation of natural forests and sustainable forestry in Cyprus. Considering the water pipe line project from Turkey, the Mesaoria Plain shows a great potential for eucalyptus plantation. As indicated by the FAO, poplar trees and eucalyptus trees are suitable on the $5 \%$ of irrigable agriculture lands, as they do not bear any negative impact.

The research studies concerning the use of waste water and sewage sludge from the Haspolat treatment plant in the eucalyptus production shall be continued, and the eucalyptus groves to be created in the region shall contribute on the fauna. The landowners that plan to plant eucalyptus trees on their lands in the Mesaoria region shall get state subsidies.

When compared with the local species, the eucalyptuses grow faster when put under the optimum conditions. The transparent and dense leaves need the inorganic matters in the soil more and consume them faster. Therefore, they are dangerous for the trees on the Kyrenia Mountains since they may deteriorate the quality of soil rich on the coastal zone where the reforestation exists. On the other hand in Mesaoria, the eucalyptus trees have a significant potential to add economic value on the inefficient areas. The eucalyptuses are the raw materials for mine pole, paper, packaging, medicine and coating industry with their wood. The flowers of eucalyptus trees may be used in the bee keeping and the trunk may be used as a windbreaker.

\section{REFERENCES}

Amazonas, N. T., Forrester, D. I., Oliveira, R. S., \& Brancalion, P. H. (2017). Combining Eucalyptus wood production with the recovery of native tree diversity in mixed plantings: Implications for water use and availability. Forest Ecology and Management.

Ashton, D. H. (1975). The root and shoot development of Eucalyptus regnans F. Muell. Australian Journal of Botany, 23(6), 867-887. https: / / doi.org/10.1071/BT9750867

Avcıŏ̆lu, E. (1989). Doğu Akdeniz Ormancıliğında Okaliptüsün Yeri ve Önemi. "Doğu Akdeniz Ormancılığı" Sempozyumu Tebliğ Metinleri. Orman Mühendisleri Odası Yayın No. 15, Ankara.

Ayata, Ü. (2008) Okaliptüs (Eucalyptus Camaldulensis ve Eucalyptus grandis)'ün Odun Özellikleri ve Kağıt Endrüstrisinde Kullanımının Araştırılması, Yüksek Lisans Tezi, Sütçü İmam Üniversitesi, Fen Bilimleri Enstitüsü, Orman Endrüstri Mühendisliği Anabilim Dalı, Kahramanmaraş.

Cunha, M., Romaní, A., Carvalho, M., \& Domingues, L. (2018). Boosting bioethanol production from Eucalyptus wood by whey incorporation. Bioresource Technology, 250, 256-264. https:/ / doi.org/10.1016/j.biortech.2017.11.023

Çepel N., (2008). Ekolojik Sorunlar ve Çözümleri. Tübitak Popüler Bilim Kitapları, Ankara.

De Toledo, G. R., Souza, G. M., \& Bertolli, S. C. (2015). Influence of root interaction in eucalyptus clones under two environmental conditions. Procedia Environmental Sciences, 29, 223-224. https:/ / doi.org/10.1016/j.proenv.2015.07.283

Görcelioğlu, E, (1988). Ormancılık ve Çevre Açısından Okaliptüs. İstanbul Üniversitesi Orman Fakültesi Dergisi, Sayı 1 , İstanbul.

Herrero, C., Juez, L., Tejedor, C., Pando, V., \& Bravo, F. (2014). Importance of root system in total biomass for Eucalyptus globulus in northern Spain. Biomass and Bioenergy, 67, 212-222. https://doi.org/10.1016/j.biombioe.2014.04.023

Işık, K. (1989). Avustralya'nın 200. Yilı Dolayısıyla Düzenlenen Milletlerarası Ormancılık Kongresive Avustralya Ormancılı̆̆ı Hakkında izlenimler. Orman Mühendisliği Dergisi, Yıl 26, Sayı 3, 1989.

İlseven, S. (2014). Kıbrıs'ın vejetasyon cografyası eğitim ve yönetimi. Yayınlanmamış Doktora Tezi, YDU, Lefkoşa.

İlseven, S. (2017). Analysis of Maquis and Garrigue communities on the island of Cyprus and comparison with Calabrian pine communities in terms of ecological characteristics. Journal of Environmental Biology, 38(5(SI)), 955-960. https:/ / doi.org/10.22438/jeb/38/5(SI)/GM-12 
İlseven, S., Hıdırer, G., \& Tümer, A. (2016). Kıbrıs Coğrafyası. Kıbrıs Milli Eğitim Bakanlığı Yayını, Başak Maatbaacılık ve Tan. Hiz. Ltd. Şti. Ankara.

Phifer, C. C., Knowlton, J. L., Webster, C. R., Flaspohler, D. J., \& Licata, J. A. (2017). Bird community responses to afforested eucalyptus plantations in the Argentine pampas. Biodiversity and Conservation, 26(13), 3073-3101. https:/ / doi.org/10.1007/s10531-016-1126-6

Türker, H. A. (2008). Tarsus Karabucak, Okaliptüs işletmeciliğiyle Civar Bölge Tarımının Ekonomik Yönden Bir Kıyaslaması. I.Ulusal Okaliptüs Sempozyumu, Bildiriler Kitabı, Kahramanmaraş Sütçü İmam Üniversitesi, Orman Fakültesi, Kahramanmaraş, Doğu Akdeniz Ormancılık Araştırma Müdürlüğü, Tarsus.

Yıkıcı, Z. (2015). Okaliptis Dünü ve Geleceği. Kıbrıs Raporu, 1879-2014.

Wellington, A. B., \& Noble, I. R. (1985). Post-fire recruitment and mortality in a population of the mallee Eucalyptus incrassata in semi-arid, south-eastern Australia. The Journal of Ecology, 645-656. https:// doi.org/10.2307/2260501

\section{http://www.ejmste.com}

